\title{
(Des)Avanços: legislação antirracista e sua aplicação
}

\author{
DOI: 10.15175/1984-2503-202214101
}

\author{
Renata Miranda Lima* \\ Raíssa Moreira Lima Mendes Musarra*
}

\section{Resumo}

A luta antirracista no Brasil vivencia um cenário de disputa de narrativas ainda inacabada, a qual enfrenta impasses no campo legal e jurídico para o alcance de sua implementação e efetividade. Toda essa disputa interfere na capacidade de concretização do Direito à igualdade disposto na Constituição da República Federativa do Brasil. Com a finalidade de somar na discussão posta quanto à efetividade da luta antirracista, este artigo traz algumas reflexões sobre seus caminhos e descaminhos no legislativo, sua aplicação no judiciário e a perpetuação de práticas racistas na construção da consciência coletiva por meio da mídia e práticas sociais na figura do "humor".

Palavra-chave: direito à igualdade; racismo estrutural; Brasil; mídia; legislação antirracista.

\section{(Retro)avances: la legislación antirracista y su aplicación}

\section{Resumen}

La lucha antirracista en Brasil vive un escenario de disputa de narrativas todavía inacabado que enfrenta impases en el ámbito legal y jurídico para lograr su implementación y efectividad. Tal disputa interfiere en la capacidad de concreción del derecho a la igualdad que establece la Constitución de la República Federal de Brasil. A fin de contribuir al debate sobre la efectividad de la lucha antirracista, este artículo reflexiona sobre sus caminos y desvíos dentro del poder legislativo, su aplicación en el poder judicial y la perpetuación de las prácticas racistas en la construcción de la conciencia colectiva a través de la medios de comunicación y las prácticas sociales en torno a la figura del «humor».

Palabras clave: derecho a la igualdad; racismo estructural; Brasil; medios de comunicación; legislación antirracista.

\footnotetext{
* Advogada, mestre, pesquisadora e professora. Especialista em negociação, conciliação e mediação em resolução de conflitos pela Universidade Castilla La Mancha - UCLM. Pós-Graduada em Direitos Fundamentais internacionais pelo Instituto Brasileiro de Ciências Criminais em parceria com a Faculdade de Direito da Universidade de Coimbra, e pós-graduada em Compliance pelo Instituto Brasileiro de Ciências Criminais em parceria com a Faculdade de Coimbra. E-mail: renatamirandalima@yahoo.com.br. (9ttp://lattes.cnpq.br/9477688103206508. (1) https://orcid.org/0000-0002-1943-906X

${ }^{*}$ Advogada, Pesquisadora da Escola Superior da Advocacia de São Paulo - ESAOAB/SP. Pesquisadora em nível de Pós-doutorado no Instituto de Energia e Ambiente da Universidade de São Paulo (IEE/USP). Pesquisadora do Research Centre for Gás Innovation (RCGI/USP). Advogada, pós-graduada em Direito Público pela Universidade Federal de Goiás, mestre e doutora em Ciências Sociais (Universidade Federal do Maranhão; Universidade Federal do Pará), com estágio doutoral sanduíche na Universidade Paris XII, Villetaneuse (Sociologie/Droit). E-mail: raissa@musarra.com.br. http://lattes.cnpq.br/0160463295876636.

(1) https://orcid.org/0000-0003-1436-406X
} 
(Dis) Advances: anti-racist legislation and its application

\begin{abstract}
The anti-racist struggle in Brazil has experienced an endless dispute among narratives, confronting obstacles in the legal field impeding its implementation and effectiveness. The entire dispute interferes with the country's ability to solidify the Right to Equality stated in the Constitution of the Federal Republic of Brazil. With the aim of contributing to the debate on the matter of the effectiveness of the anti-racist struggle, this article provides reflections on its paths and setbacks in the legislative sphere, its application in the courts, and the perpetuation of racist practices in the building of the collective conscience by means of the media and social practices by way of "humor".
\end{abstract}

Keywords: Right to equality; structural racism; Brazil; media; anti-racist legislation.

\title{
Reculs et avancées : la législation antiraciste et son application
}

\section{Résumé}

La lutte contre le racisme au Brésil est la scène d'un conflit de récits encore inachevé, et se trouve confrontée dans le champ légal et juridique à des obstacles à sa mise en œuvre effective. Cette conflictualité interfère dans la capacité de concrétisation du droit à l'égalité stipulé par la Constitution de la République fédérative du Brésil. Dans le but de contribuer au débat sur l'effectivité de la lutte antiraciste, cet article propose des réflexions sur ses avancées et ses reculs dans le cadre législatif, sur son application dans la sphère judiciaire et sur la perpétuation de pratiques racistes dans la construction de la conscience collective à travers les médias et dans les pratiques sociales sous la forme de l'« humour ".

Mots-clés : droit à l'égalité ; racisme structurel ; Brésil ; médias ; législation antiraciste.

\section{进展与退步：巴西反种族主义立法及其实施}

\section{摘要}

巴西的反种族主义斗争经历了一个漫长时期，其历史任务尚未完成，至今仍然存在一些争议，在立法和司法领 域产生了一些僵局亟需解决，以促进《反种族主义法》能够得到顺利、有效的实施。这些争议干扰了巴西联邦 共和国宪法规定的种族平等权的实施。为了促进巴西关于反种族主义斗争的讨论，本文对反种族主义运动在立 法机构中斗争的路径和偏差、它在司法实践中的困境，以及种族主义行为在巴西集体意识中的延续进行了一些 反思。这些种族主义行为反映在巴西媒体的娱乐和“幽默”节目中，反映在日常社会实践中，并形成了一种根深 蒂固的集体意思和无意识。

关键词：平等权；结构性种族主义；巴西；媒体；反种族主义立法

Valores racistas reproduzidos socialmente afetam as possibilidades sociais e econômicas para negros, pois representações sociais como "não qualificados, preguiçosos, desorganizados, violentos, sujos, animais, criminosos" (MOREIRA, 2019, p. 55) - a maioria herdada da escravidão - definem a imaginário social de negros e não-negros e justificam a exclusão de negros de determinadas posições sociais e profissionais. 
Essas representações sociais alcançam a toda população negra, independentemente de sua idade e de sua classe social, pois são baseadas em cor e origem, e, assim, nem crianças estão isentas. O exposto fica evidenciado em discriminação racial em que uma criança negra foi expulsa da calçada de uma loja privada em que esperava seu pai, norte-americano Jonathan Duran. Uma funcionária solicitou que saísse a fim de não "prejudicar" a imagem da marca. Houve a absolvição da empresa mediante a justificativa de mera discriminação social, ausentando elementos de raça que motivassem o caso (QUEIROZ, 2019). Ou seja, além da ineficiência no texto legal para o início de processamento dos crimes respectivos há a interpretação dos tribunais que desclassificam os crimes por meio do argumento de se tratar de mera discriminação social, ou porque foi desenvolvido em cenário de briga ou, por se tratar de ínfima brincadeira. Insultos raciais são manifestações que reproduzem e reforçam os estereótipos raciais (MACHADO; LIMA; NERIS, 2016).

Assim, considera-se que, apesar dos avanços, ainda estamos diante de um cenário em que há a falta de medidas capazes de efetivar a legislação antirracista, pois estes se despontam de ações diretas e indiretas que, em razão de sua prática reiterada e sistemática, ficam adormecidos na consciência social, a ponto de manifestarem-se nas publicidades, novelas, filmes e músicas, tecendo valores negativos à população negra.

Toda essa conjuntura reforça a representação do lugar social subalterno desses indivíduos, inclusive nos postos de trabalho. A este respeito, Oracy Nogueira (1985) assevera por meio dos resultados alcançados em sua pesquisa que empregadores entrevistados achavam "muito natural" sua preferência por empregados brancos. O autor conclui que essa preferência está baseada em argumentos depreciativos em relação aos negros de que esses roubam, não são higiênicos, desobedecem, são indisciplinados, tem inadequação para lidar com crianças, cheiro ruim e são preguiçosos (NOGUEIRA, 1985).

Esta conclusão decorre de diversos casos de racismo materializados em publicações nacionais. O caso notório mais recente de racismo publicitário veio a público em abril de 2020, mediante diversos protestos antirracistas em todo o mundo. Tratou-se de publicidade da maior marca de palhas de aço nacional, a Bombril, com alta capacidade de investimento em esforços publicitários. No caso em tela, a agência propôs a divulgação de um produto historicamente problemático, a "Krespinha", publicamente humilhando cabelos crespos naturais e a imagem de pessoas pretas (BOMBRIL..., 2020). A propaganda apenas saiu do ar mediante esforços dos próprios consumidores, os quais organizaram ação de boicote e exposição da marca. Trata-se de uma evidente demonstração da permanência do caráter 
discriminatório na publicidade, mesmo falando em canais de alto investimento e grande repercussão publicitária.

Para além do caso Bombril, é possível apontar a publicidade da Cervejaria Devassa, da Schincariol, que publicou nos dias 28/11/2010 e 05/12/2010 na revista do jornal A Gazeta a imagem de uma mulher negra com a frase: "É pelo corpo que se reconhece a verdadeira negra. Devassa negra encorpada. Estilo dark ale de alta fermentação. Cremosa com aroma de malte torrado” ('É PELO CORPO..., 2012). Essa revista era distribuída em todos estados do Brasil. Diante desse anúncio, três mulheres, de estados diferentes, ingressaram com ações individuais pedindo reparação de danos alegando que enquanto andavam penas ruas ouviam comentários tais como: "essa é a verdadeira devassa" e "que dá vontade de beber" e por isso sentiam que tinham mais medo de serem estupradas, pois o comercial as expõe sexualmente. Apesar da movimentação das mulheres e ações judiciais, a decisão foi de improcedência pela $9^{a}$ vara Cível de Vitória/ES pelo juiz de Direito Carlos Alexandre Gutmann, o qual concluiu que "a propaganda não é abusiva ou discriminatória”, pois não "há qualquer mensagem racista, sendo o anúncio original, irreverente, refletindo uma essencialidade, autenticidade e alegria” (BRASIL, 2013; NÃO É OFENSIVA..., 2013, par. 2). Com a finalidade de tornar mais ilustrativo segue a figura publicitária que ocupou duas páginas da revista.

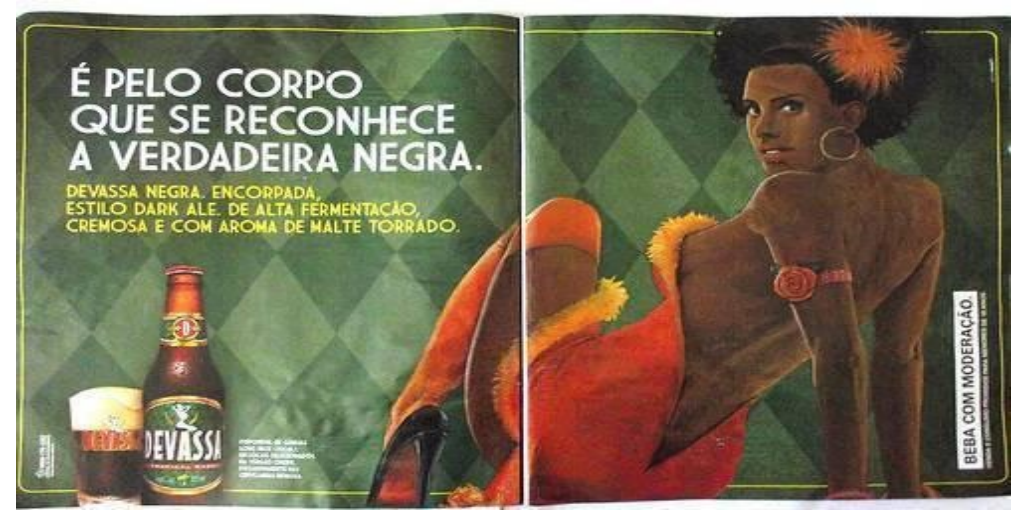

Fonte: devassa_racista_negra.jpg (500×327) (exactdn.com)

Outro exemplo mais recente foi o caso "Dove" em que a empresa, juntamente com a Unilever, publicou, em 2017, propaganda apresentando os seus produtos com uma muIher negra tirando uma camisa cor marrom e depois uma mulher branca com uma camiseta aspecto claro, indicando um melhoramento (SANTAHELENA, 2017). Com a finalidade de tornar mais ilustrativo segue a figura publicitária usada na campanha do produto "Dove". 


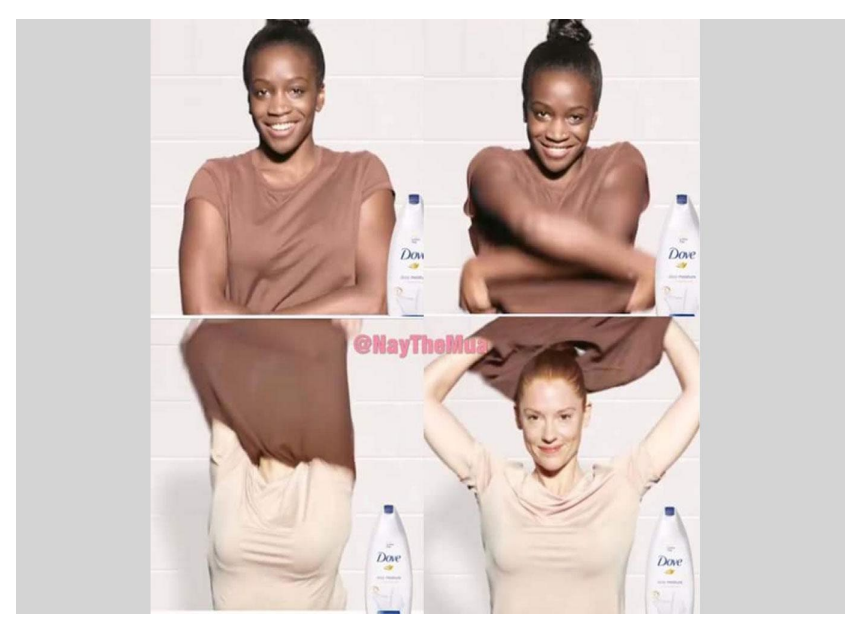

Os anúncios corroboram a urgência na construção do compromisso publicitário, legal e judiciário antirracista, pois a mídia continua produzindo publicidades que deterioram a imagem da população negra no Brasil, inferiorizando e sexualizando-a, e a sociedade brasileira tem assistido uma omissão, tanto do judiciário como do legislativo, na promoção de mecanismos capazes de coibir tais práticas.

Desde a década de 1950, quando o preconceito de raça ou cor se tornou contravenção penal na Lei no 1.390 (BRASIL, 1951), a população negra brasileira passou a acessar o Poder Judiciário para denunciar conflitos raciais. Em 1988 com a Constituição Federal, o racismo passou a ser considerado crime inafiançável e imprescritível (BRASIL, 1988). No ano seguinte, a Lei infraconstitucional $n^{\circ} 7.716$ (BRASIL, 1989) definiu as práticas de racismo. Em 1997 a lei 9.459 criou o tipo penal de injúria racial que tinha natureza de ação privada (BRASIL, 1997) e com a lei 12.033 (BRASIL, 2009) a ação passou a ser pública, contudo, condicionada a representação.

Assim, a legislação brasileira prevê duas formas para lidar com o racismo. Uma se materializa no crime de racismo ${ }^{1}$ e a outra no crime de injúria racial. ${ }^{2}$ A principal diferença na tipificação desses crimes consiste na natureza da ação penal. No crime de racismo a ação penal é pública incondicionada, ou seja, na ocorrência da conduta típica, qualquer pessoa pode levá-la ao conhecimento da autoridade policial e essa deverá iniciar a investigação policial para que o Ministério Público ofereça -ou não- a denúncia, judicializando a questão (NUCCI, 2015). Enquanto na injúria racial, a ação penal é pública condicionada a

\footnotetext{
${ }^{1} \mathrm{O}$ crime de racismo é caracterizado por uma conduta discriminatória dirigida a um determinado grupo ou coletividade.

2 Já a injúria racial, é a ofensa à honra de uma pessoa, usando, para isso, elementos como a raça, cor, etnia, religião. O bem juridicamente protegido no crime de injúria racial é a honra subjetiva de alguém específico.
} 
representação do ofendido e, diante da ocorrência do crime de injúria racial, previsto no artigo 140, $\S 3^{\circ}$ e 145, parágrafo único do Código Penal, ${ }^{3}$ a vítima deve informar a delegacia e, em outro momento, deverá apresentar formalmente seu interesse de que se proceda a investigação do caso no prazo de seis meses.

\author{
Injúria \\ Art. 140 - Injuriar alguém, ofendendo-lhe a dignidade ou o decoro: \\ Pena - detenção, de um a seis meses, ou multa. \\ $\S 1^{\circ}$ - O juiz pode deixar de aplicar a pena: \\ I - quando o ofendido, de forma reprovável, provocou diretamente a injúria; \\ II - no caso de retorsão imediata, que consista em outra injúria. \\ $\S 2^{\circ}$ - Se a injúria consiste em violência ou vias de fato, que, por sua natureza ou \\ pelo meio empregado, se considerem aviltantes: \\ Pena - detenção, de três meses a um ano, e multa, além da pena correspondente à \\ violência. \\ § 3o Se a injúria consiste na utilização de elementos referentes a raça, cor, etnia, \\ religião, origem ou a condição de pessoa idosa ou portadora de deficiência: \\ Pena - reclusão de um a três anos e multa (BRASIL, 1940, art. 140).
}

Assim, para a caracterização do crime, é necessário que haja ofensa à dignidade de alguém, com base em elementos referentes à sua raça, cor, etnia, religião, idade ou deficiência, em cujas hipóteses a pena aumenta para 1 a 3 anos de reclusão.

Outro instrumento relevante no cenário da legislação antirracista é a Lei $n^{0} 7.716$, de 5 de janeiro de 1989, que define os crimes resultantes de preconceito de raça ou de cor, define a punição para "os crimes resultantes de discriminação ou preconceito de raça, cor, etnia, religião ou procedência nacional” (BRASIL, 1989, art $1^{\circ}$ ). Entre eles estão previstas condutas como impedir o acesso de uma pessoa devidamente habilitada a um cargo público ou negar emprego na iniciativa privada, que podem render penas de dois a cinco anos de reclusão, ações como impedir inscrição de aluno em estabelecimento de ensino, recusar hospedagem em hotel ou similar, recusar atendimento em bares ou restaurantes e em barbearias.

Negar ou obstar emprego em empresa privada é a conduta de pena mais elevada, de reclusão de dois a cinco anos, incorrendo na mesma pena quem, por motivo de discri-

\footnotetext{
${ }^{3}$ Brasil (1940, arts. 140; 145): Decreto Lei 2.848. Código Penal:

Art. 140 - Injuriar alguém, ofendendo-Ihe a dignidade ou o decoro:

$\S 3^{\circ} \mathrm{Se}$ a injúria consiste na utilização de elementos referentes a raça, cor, etnia, religião, origem ou a condição de pessoa idosa ou portadora de deficiência:

Pena - reclusão de um a três anos e multa.

Art. 145 - Nos crimes previstos neste Capítulo somente se procede mediante queixa, salvo quando, no caso do art. $140, \S 2^{\circ}$, da violência resulta lesão corporal.

Parágrafo único. Procede-se mediante requisição do Ministro da Justiça, no caso do inciso I do caput do art. 141 deste Código, e mediante representação do ofendido, no caso do inciso II do mesmo artigo, bem como no caso do $\S 3$ o do art. 140 deste Código.
} 
minação de raça ou de cor ou práticas resultantes do preconceito de descendência ou origem nacional ou étnica: I - deixar de conceder os equipamentos necessários ao empregado em igualdade de condições com os demais trabalhadores; II - impedir a ascensão funcional do empregado ou obstar outra forma de benefício profissional; III - proporcionar ao empregado tratamento diferenciado no ambiente de trabalho, especialmente quanto ao salário. Vale frisar que por força da lei, ficará sujeito às penas de multa e de prestação de serviços à comunidade, incluindo atividades de promoção da igualdade racial, quem, em anúncios ou qualquer outra forma de recrutamento de trabalhadores, exigir aspectos de aparência próprios de raça ou etnia para emprego cujas atividades não justifiquem essas exigências. Estes dispositivos de equiparação da pena de reclusão de 2 a 5 anos foram incluídos apenas em 2010, com o advento da Lei nº 12.288 daquele ano (BRASIL, 2010, art. $4^{\circ}$ ).

Contudo, condutas como recusar ou impedir acesso a estabelecimento comercial, negando-se a servir, atender ou receber cliente ou comprador tem pena mais branda, de reclusão de um a três anos, mesma pena para quem impedir o acesso ou recusar hospedagem em hotel, pensão, estalagem, ou qualquer estabelecimento similar; impedir o acesso ou recusar atendimento em restaurantes, bares, confeitarias, ou locais semelhantes abertos ao público; impedir o acesso ou recusar atendimento em estabelecimentos esportivos, casas de diversões, ou clubes sociais abertos ao público; impedir o acesso ou recusar atendimento em salões de cabeleireiros, barbearias, termas ou casas de massagem ou estabelecimento com as mesmas finalidades; impedir o acesso às entradas sociais em edifícios públicos ou residenciais e elevadores ou escada de acesso aos mesmos; e impedir o acesso ou uso de transportes públicos, como aviões, navios barcas, barcos, ônibus, trens, metrô ou qualquer outro meio de transporte concedido.

E quanto ao ato de recusar, negar ou impedir a inscrição ou ingresso de aluno em estabelecimento de ensino público ou privado de qualquer grau, a pena torna a ser a de reclusão de três a cinco anos, agravada de um terço se o crime for praticado contra menor de dezoito.

Já as condutas de impedir ou obstar o acesso de alguém ao serviço em qualquer ramo das Forças Armadas tem pena de reclusão de dois a quatro anos prevista, da mesma maneira é a conduta de impedir ou obstar, por qualquer meio ou forma, o casamento ou convivência familiar e social.

Importante notar que constitui efeito da condenação a perda do cargo ou função pública, para o servidor público que promover as condutas descritas, e a suspensão do funci- 
onamento do estabelecimento particular em que ocorreram as condutas, por prazo não superior a três meses. Tais efeitos não são automáticos, devendo ser motivadamente declarados na sentença.

Em 1997, foram introduzidas na lei Caó (BRASIL, 1985) as penas de reclusão de um a três anos e multa a quem praticar, induzir ou incitar a discriminação ou preconceito de raça, cor, etnia, religião ou procedência nacional, tendo como agravantes as condutas de fabricar, comercializar, distribuir ou veicular símbolos, emblemas, ornamentos, distintivos ou propaganda que utilizem a cruz suástica ou gamada, para fins de divulgação do nazismo, subindo a pena para reclusão dois a cinco anos e multa. O mesmo aumento de pena dáse a quem praticar, induzir ou incitar a discriminação ou preconceito de raça quando as condutas forem cometidas por intermédio dos meios de comunicação social ou publicação de qualquer natureza. Facultado, neste caso, ao juiz determinar, ouvido o Ministério Público ou a pedido deste, ainda antes do inquérito policial, o recolhimento imediato ou a busca e apreensão dos exemplares do material respectivo; a cessação das respectivas transmissões radiofônicas, televisivas, eletrônicas ou da publicação por qualquer meio; a interdição das respectivas mensagens ou páginas de informação na rede mundial de computadores.

Caso não oferecida a representação, procede-se o arquivamento da notícia crime. ${ }^{4}$ Portanto, diante da ocorrência do crime de injúria racial, ainda que informado à autoridade policial, tal registro não gera por si só o prosseguimento da investigação, fazendo-se necessária a representação da vítima (BRASIL, 1940). ${ }^{5}$ Contudo, por falta de informação, as vítimas podem não fazer a representação, gerando o arquivamento da notícia crime sem qualquer investigação policial.

Observa-se que, tanto as ações privadas como as condicionadas necessitam de provocação do ofendido para o início das investigações policiais (BRASIL, 1940; NUCCI,

\footnotetext{
${ }^{4}$ Brasil (1941, art. 38): Código de Processo Penal:

Art. 38. Salvo disposição em contrário, o ofendido, ou seu representante legal, decairá no direito de queixa ou de representação, se não o exercer dentro do prazo de seis meses, contado do dia em que vier a saber quem é o autor do crime, ou, no caso do art. 29, do dia em que se esgotar o prazo para o oferecimento da denúncia.

5 Brasil (1940, arts. 140; 145, grifo nosso):

Art. 140 - Injuriar alguém, ofendendo-Ihe a dignidade ou o decoro:

$\S 3^{\circ}$ Se a injúria consiste na utilização de elementos referentes a raça, cor, etnia, religião, origem ou a condição de pessoa idosa ou portadora de deficiência:

Pena - reclusão de um a três anos e multa.

Art. 145 - Nos crimes previstos neste Capítulo somente se procede mediante queixa, salvo quando, no caso do art. $140, \S 2^{\circ}$, da violência resulta lesão corporal.

Parágrafo único. Procede-se mediante requisição do Ministro da Justiça, no caso do inciso I do caput do art. 141 deste Código, e mediante representação do ofendido, no caso do inciso II do mesmo artigo, bem como no caso do $\S 3$ ㅇ do art. 140 deste Código.
} 
2015). Ou seja, a autoridade policial não inicia de ofício a investigação. Assim, considerase que, apesar da mudança da natureza da ação penal de privada para pública, essa resta condicionada a representação. É justamente na necessidade de representação que persiste a ineficiência da lei no que tange aos crimes de injúria racial.

Esta cominação de pena é importante pois determina o potencial de aplicação da suspensão condicional da pena, por força do artigo 77 do Código Penal, introduzido pela Lei n. 7.209 (BRASIL, 1984). Já que os requisitos da suspensão da pena são que, quando haja execução da pena privativa de liberdade, não superior a 2 (dois) anos, a mesma poderá ser suspensa, por 2 (dois) a 4 (quatro) anos, desde que: I - o condenado não seja reincidente em crime doloso; II - a culpabilidade, os antecedentes, a conduta social e personalidade do agente, bem como os motivos e as circunstâncias autorizem a concessão do benefício. Observe-se que podem, diante do artigo 44 do Código Penal, as penas privativas de liberdade não superiores a quatro anos, quando o crime não seja cometido com violência ou grave ameaça ou, ainda, quando o crime seja culposo, ser substituídas pelas penas restritivas de direito. ${ }^{6}$

Sem deslegitimar a necessidade do instituto e seu estímulo pela diminuição da superlotação no cárcere e das penas alternativas para condutas de menor complexidade, vale a pena a reflexão da permissibilidade do instituto em relação aos crimes motivados por

\footnotetext{
${ }^{6}$ Brasil (1940, art. 44):

Art. 44. As penas restritivas de direitos são autônomas e substituem as privativas de liberdade, quando: (Redação dada pela Lei nº 9.714 , de 1998)

I - aplicada pena privativa de liberdade não superior a quatro anos e o crime não for cometido com violência ou grave ameaça à pessoa ou, qualquer que seja a pena aplicada, se o crime for culposo;(Redação dada pela Lei $n^{\circ} 9.714$, de 1998)

II - o réu não for reincidente em crime doloso; (Redação dada pela Lei nº 9.714, de 1998)

III - a culpabilidade, os antecedentes, a conduta social e a personalidade do condenado, bem como os motivos e as circunstâncias indicarem que essa substituição seja suficiente. (Redação dada pela Lei $n^{\circ} 9.714$, de 1998)

$\S 10$ (VETADO) (Incluído pela Lei nº 9.714, de 1998)

§ $20 \mathrm{Na}$ condenação igual ou inferior a um ano, a substituição pode ser feita por multa ou por uma pena restritiva de direitos; se superior a um ano, a pena privativa de liberdade pode ser substituída por uma pena restritiva de direitos e multa ou por duas restritivas de direitos. (Incluído pela Lei $n^{\circ}$ 9.714, de 1998)

$\S 30$ Se o condenado for reincidente, o juiz poderá aplicar a substituição, desde que, em face de condenação anterior, a medida seja socialmente recomendável e a reincidência não se tenha operado em virtude da prática do mesmo crime. (Incluído pela Lei $n^{\circ} 9.714$, de 1998)

$\S 40$ A pena restritiva de direitos converte-se em privativa de liberdade quando ocorrer o descumprimento injustificado da restrição imposta. No cálculo da pena privativa de liberdade a executar será deduzido o tempo cumprido da pena restritiva de direitos, respeitado o saldo mínimo de trinta dias de detenção ou reclusão. (Incluído pela Lei n 9.714, de 1998)

§ 50 Sobrevindo condenação a pena privativa de liberdade, por outro crime, o juiz da execução penal decidirá sobre a conversão, podendo deixar de aplicá-la se for possível ao condenado cumprir a pena substitutiva anterior. (Incluído pela Lei n 9.714, de 1998)
} 
questões raciais diante do papel crucial que a imposição de penas mais duras pode efetivar para o tratamento macro do condenatório e repressor do racismo estrutural na sociedade.

Após esse primeiro impasse legislativo apresentado, destaca-se que há outros pontos que inviabilizam a efetividade da lei. É exemplo a situação em que, apesar de ter ocorrido a representação da vítima com a juntada das provas testemunhais no inquérito policial para que a investigação culmine em ação penal no caso de injúria racial, ou diante de crime de racismo - que não depende de representação para que se encaminhe a investigação policial, o processamento judicial depende do Ministério Público, que é o único titular das ações penais no Brasil (NUCCl, 2015), que pode manifestar-se pelo arquivamento do inquérito, por entender que não haja reunião de provas necessárias à ação, ou pode oferecer a denúncia, caso entenda pela existência de provas necessárias à ação penal. É possível ao órgão, também, requerer a extinção da punibilidade conforme hipóteses legais previstas taxativamente no Código Penal (BRASIL, 1940), ou requerer o retorno dos autos à polícia judiciária para dar continuidade à investigação (NUCCl, 2015).

Destaca-se que o controle desse arquivamento é feito pela autoridade judiciária (NUCCI, 2015). Contudo, a ação penal pública condicionada à representação é regida por dois princípios, quais sejam, o da oportunidade e o da obrigatoriedade. Inicialmente, o órgão do Ministério Público delibera por apresentar - ou não - a denúncia, pautado no princípio da oportunidade. Caso esse ofereça a denúncia, então passará a vigorar o princípio da obrigatoriedade (NUCCl, 2015). Portanto, ainda que o requerimento de arquivamento passe por uma análise judicial, em razão de se situar na fase que vige o princípio da oportunidade, nesse primeiro momento, na prática, não há grande ingerência do judiciário.

Então, caso o ofendido ofereça representação, o segundo impasse legislativo está ancorado na manifestação do Ministério Público, pois, ainda que o requerimento de arquivamento passe pela análise judicial, a ausência de regulação para o arquivamento de crimes de racismo e injúria racial gera arbitrariedade, dado que, tão somente a hipótese de extinção de punibilidade é regulada em lei. ${ }^{7}$ Assim, com base no exposto, entende-se que

\footnotetext{
${ }^{7}$ Brasil (1940, art. 107):

Extinção da punibilidade

Art. 107 - Extingue-se a punibilidade:

I - pela morte do agente;

II - pela anistia, graça ou indulto;

III - pela retroatividade de lei que não mais considera o fato como criminoso;

IV - pela prescrição, decadência ou perempção;

$\checkmark$ - pela renúncia do direito de queixa ou pelo perdão aceito, nos crimes de ação privada;

VI - pela retratação do agente, nos casos em que a lei a admite;

VII - $\quad$ (Revogado pela Lei $n^{\circ} 11.106$, de 2005)
} 
a não regulamentação das hipóteses em que caberia o arquivamento da ação, especificamente nos casos de crime de raça e cor, gera campo propício para arbitrariedade das autoridades competentes, pois somente embasados em sua análise de cabimento, os órgãos do Ministério Público processam, ou não, o crime de injúria racial.

Nesse ínterim, pesquisas corroboram as falhas legislativas que inviabilizam a efetividade da lei. Pesquisa divulgada pelo Ministério Público do Distrito Federal e dos Territórios (MPDFT) demonstra que o número de denúncias de crimes relacionados a discriminação racial subiu 1.119\% entre 2010 e 2016 (ÁVILA, 2017). O baixo número pode estar atrelado à estrutura legal que dificulta o início das ações de injúria racial e racismo. Outra questão importante diz respeito ao fato de que, dentre os casos que se tornaram denúncia, $46 \%$ foram solucionados com o acordo processual de suspensão condicional do processo, com aplicação imediata de penas alternativas (ÁVILA, 2017). Considera-se que a aplicação de penas alternativas enfraquece o sistema legal antirracista que, apesar de prever pena de reclusão ao racismo e de ser considerado crime inafiançável e imprescritível, na prática, o judiciário tende a aplicar penas alternativas.

Destaca-se que a Legislação no Estado de São Paulo n 14.187/10 - SP e o Decreto Estadual 63.979/18 regulam a prática de discriminação (SÃO PAULO, 2010, 2018). Contudo, têm vigência e aplicação somente estadual e entre a instauração da lei estadual de 2010 e a data de 18.09.2019, houve apenas 421 denúncias no Estado de São Paulo (cerca de 40 denúncias por ano).

Em atenção à Lei no 12.527 (BRASIL, 2011) (Lei de Acesso à Informação), no dia 24 de setembro de 2019 a Secretaria de Estado da Justiça e da Cidadania de São Paulo informou que "foram registradas deste a criação da Lei de 2010 até 18.09.2019 um total de 421 denúncias". ${ }^{8}$ Adicionalmente, informou que

as denúncias recebidas pela Secretária da Justiça e Cidadania passam por uma triagem junto a Coordenação de Políticas Públicas para População Negra e Indígena - CPPNI e pela análise da Chefia de Gabinete da pasta, bem como parte das denúncias recebidas passam por Sessão de Mediação de Conflitos (Conciliação) em parceria com Tribunal de Justiça do Estado de São Paulo, que tem como principal objetivo resolver o conflito de forma pacífica e sem instauração do processo administrativo de discriminação racial.

VIII - $\quad$ (Revogado pela Lei $n^{\circ} 11.106$, de 2005)

IX - pelo perdão judicial, nos casos previstos em lei.

${ }^{8}$ Trata-se de arquivo pessoal. Comunicação institucional da Secretaria de Estado da Justiça e da Cidadania de São Paulo com as pesquisadoras através do site sic http://www.sic.sp.gov.br/, acesso por meio de login e senha pessoal. 
Cumpre destacar que as sanções aplicáveis, nos casos de práticas de atos de discriminação, previstas no respectivo diploma legal no artigo $6^{\circ}$, são:

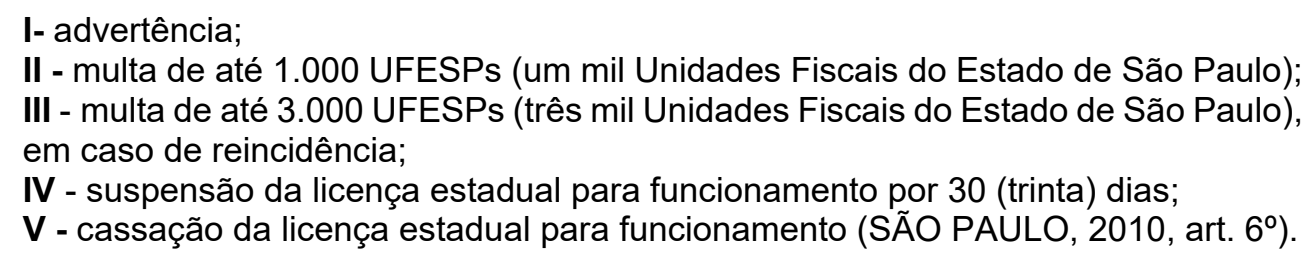

Nesse sentido, com relação às denúncias que foram investigadas, a secretaria informou que o "total de condenações (denúncias procedentes) foi 83 e o total de absolvições (denúncias improcedentes) foi 33" e os demais 305 casos foram resolvidos por conciliação. Isso implica dizer que, em São Paulo, apenas $27,55 \%$ dos casos se transformam em processos judiciais com algum tipo de decisão, enquanto 305 casos resolvidos por meio de conciliação, o que corresponde a quase $70 \%$ dos casos. Ante o exposto, torna-se visível a criação de prerrogativa de audiências de conciliação e mediação para crime de racismo e injúria racial, minimizando a gravidade das ações, o que não ocorre em crimes que não são considerados pela Constituição como imprescritíveis e inafiançáveis como crimes patrimoniais (BRASIL, 1988).

A aplicação de conciliação e mediação nestes crimes não têm fundamento legal na lei estadual 14.187 (SÃO PAULO, 2010), na Constituição Federal (BRASIL, 1988) ou no Código Penal (BRASIL, 1940). É incabível o uso de métodos de resolução de conflitos alternativos em problemas estruturais como é o caso de racismo ou injúria racial. Portanto, resolver crime que estabelece como pena a reclusão no Código Penal é um caminho que deve ser afastado (BRASIL, 1940) especialmente porque não há fundamento no conjunto de leis de combate ao racismo de aplicação nacional (BRASIL, 1951, 1989) por medidas de conciliação por meio de lei estadual. Ainda, destaca-se que seria o mesmo que nos crimes de cor ou racismo cometidos em São Paulo, que teriam menor rigor de aplicação penal do que nos outros estados da federação.

Ainda quanto à efetividade da Lei antirracista, a autora Sueli Carneiro (1996), após estudar a performance da Lei e do Judiciário brasileiro, apontou como obstáculos à sua efetividade a "tipificação precária do crime de racismo" e "o descaso com que a discriminação racial é tratada no Brasil, que corriqueiramente desqualifica o crime de racismo, classificando-o como injúria ou difamação" (CARNEIRO, 1996, p. 61). Segundo a autora essa é "uma maneira de escamotear o grau de incidência da discriminação racial no Brasil" (CARNEIRO, 1996, p. 61). 
Outra pesquisa (MACHADO; LIMA; NERIS, 2016) aprofunda o exposto e aponta para os desafios à efetividade da Lei antirracista no Brasil no que tange à fase processual, especialmente nos crimes de injúria racial, que demonstra que ainda persiste a ineficácia da lei em razão da dificuldade do judiciário de conectar o tratamento dado pelo Direito Penal à dinâmica social e aos efeitos dessa prática na sociedade brasileira. Para tanto, a pesquisa apresenta dados resultantes de estudo empírico jurisprudencial sobre a aplicação pelos tribunais brasileiros entre 1998 e 2010 (MACHADO; LIMA; NERIS, 2016). O objetivo deste estudo foi "analisar a forma como os mecanismos legais antirracistas brasileiros têm funcionado e os principais obstáculos à sua aplicação à dinâmica social" (MACHADO; LIMA; NERIS, 2016, p. 11). A pesquisa se concentrou na análise de 200 ações de segunda instância distribuídos nos nove Tribunais de Justiça do Brasil. Ela focou em compreender a dinâmica da aplicação da lei, a utilização dos conceitos e argumentos jurídicos, os empecilhos e gargalos que operam para gerar a sensação generalizada de insatisfação e de impunidade.

Segundo o estudo, dos 200 casos analisados ,194 se referiam a insultos raciais, ou seja, injúria racial. Destes, apenas em 1 houve o reconhecimento de que o xingamento de cunho racial também seria uma forma de "praticar ou incitar o preconceito" (MACHADO; LIMA; NERIS, 2016, p. 15). Todos os demais foram classificados ou como injúria racial ou como injúria simples, e muitos deles acabaram não sendo reconhecidos como crimes (MACHADO; LIMA; NERIS, 2016). Dos 200 casos, “apenas 94 foram de mérito”, em que houve 54 condenações e 40 absolvições e as demais 106 decisões os tribunais não se manifestaram quanto ao mérito. As condenações foram por injúria racial em trinta casos, crime contra a honra em sua forma simples em quinze casos, prática ou incitação ao preconceito em quatro casos, conduta discriminatória em quatro casos e um caso de desacato a funcionário público (MACHADO; LIMA; NERIS, 2016). Desse conjunto de crimes contra a honra, de forma simples, em quinze casos a dimensão racial da conduta ilícita foi absolvida e as razões estavam ligadas à falta de provas; ou que o fato não constituía infração penal. A alegação de falta de provas refere-se a dois tipos de problema: prova testemunhal fraca, contraditória ou a falta de prova da intenção de discriminar. A este respeito a pesquisa destaca que:

Chamam a atenção os casos em que, não obstante o teor racista do xingamento, o tribunal reconheceu apenas a injúria simples, desconsiderando o elemento racial do conflito e definindo-o apenas como um crime contra a honra pessoal. Para explicitar a lógica de tais decisões, trazemos aqui algumas delas. Em um dos casos, em que o ofensor proferiu o xingamento "negro de merda", a acusação e o juiz de primeira instância haviam classificado o xingamento como injúria racial, mas o tribunal de Justiça o reclassificou para injúria simples. A decisão afirmou que a expressão "negro de merda" 
seria tão ofensiva quanto "grandalhão de merda" ou "baixinho de merda", sendo o primeiro elemento tão somente indicador do destinatário da ofensa. Ressaltou-se ainda que, para que tal expressão, "negro de merda", seja elemento de ofensa a integrar o tipo de injúria qualificada, seria necessário que a palavra "negro" traduzisse ânimo discriminatório, preconceituoso. ${ }^{9}$ Percebe-se aqui que a estratégia utilizada foi a desconstrução da particularidade da ofensa racial, tirando justamente o peso desse atributo nas ofensas. Como se, na sociedade brasileira, ser baixinho ou ser negro funcionasse como categorias com a mesma equivalência de ofensa e consequência para o pertencimento à sociedade (MACHADO; LIMA; NERIS, 2016, p. 17).

Assim, verifica-se que na maior parte dos casos, os tribunais brasileiros exigem a comprovação do dolo específico de discriminar ou ofender a raça e a etnia. A pesquisa aponta caso emblemático em que a vítima foi ofendida por "preta sem nome" e "vou te bater sua negra safada", e o tribunal desclassificou o caso de injúria racial para injúria simples. Afirmou que, embora a querelante tenha comprovado suas alegações por meio das testemunhas, as provas se fizeram em relação aos xingamentos, mas não se demonstrou que o objetivo da querelada era ofender a etnia da querelante (MATO GROSSO DO SUL, 2005).

Um dos aspectos importantes no entendimento dessa questão é a necessidade de comprovação de elemento intencional específico, aspecto que fundamenta muitos casos de absolvição de discriminação (MACHADO; LIMA; NERIS, 2016). Outro caso estudado pela pesquisa diz respeito a porteiros de um estabelecimento noturno que condicionaram a entrada do ofendido ao pagamento de dez reais, alegando que por ele ser "preto" teria que pagar, enquanto as outras pessoas que acompanhavam a vítima, todas de cor branca, não precisariam fazê-lo. O tribunal decidiu que a prova colhida não era suficiente para a condenação, pois não teria restado comprovada a motivação racista como razão da discriminação sofrida pela vítima. Assim, a pesquisa conclui que os tribunais brasileiros exigem para a corporificação da discriminação racial ou injúria racial a comprovação da intenção consciente e voluntária racista, o que é elemento subjetivo do dolo e está na esfera íntima da pessoa (MACHADO; LIMA; NERIS, 2016).

Outro ponto destacado pela pesquisa diz respeito à não efetividade da legislação porque a injúria racial majoritariamente ocorre em uma discussão, em cenário de disputa ou de "brincadeiras". Assim, a absolvição se justifica por ter se desenvolvido no calor da discussão ou por ser mera "brincadeira sem intenção de ofender", ficando ausente o elemento subjetivo do dolo de injuriar. A pesquisa traz como exemplo o seguinte caso:

O ofensor profere frases como "Você não sabe quem sou eu", "Só poderia ser da sua cor, você deveria estar numa jaula" e "Basta olhar pra mim e pra essa coisa pra

${ }^{9}$ SÃO PAULO. Tribunal de Justiça do Estado de São Paulo - TJSP. Apelação Criminal n. 48272000. São Paulo: TJSP, 2000. 
saber quem tem razão". A condenação em primeira instância foi por injúria simples, e o tribunal absolveu o réu, afirmando não se pode falar em injúria por ausência de elemento subjetivo quando as expressões são proferidas no "calor da discussão"; "as partes estavam de cabeça quente" (MACHADO; LIMA; NERIS, 2016, p. 19).

Quanto a absolvição sob o argumento de se tratar de brincadeira destaca-se um caso emblemático que ganhou destaque no debate público nos anos 1990 quando o cantor Tiririca e o diretor da Sony Music foram denunciados em razão da letra de uma de suas músicas: "Veja os cabelos dela, parece Bombril de arear panela. Quando ela passa, me chama atenção. Mas seus cabelos, não tem jeito, não. A catinga quase que me desmaiou. Olha, eu não aguento o seu fedô. Veja os cabelos dela"10. Após longo processo, o tribunal absolveu os réus, afirmando que ficou provado nos autos que o cantor havia composto a música para sua mulher, e ainda foi ressaltado que eles fizeram a música:

Sem o objetivo de ofender quem quer que fosse. Além disso, ao ler a letra da música pensa-se estar diante de algo de brincadeira, sem seriedade, ou seja, o réu não teve a intenção deliberada (dolo direto) de praticar, incitar a discriminação ou o preconceito de cor, assim sendo, não se concebe a existência de crime quando o agente não tem intenção de discriminar (RIO DE JANEIRO, 1998).

Todos os casos citados demonstram questões comuns que geram a ineficiência da lei no judiciário, bem como trazem interessantes interfaces entre as práticas sociais e a interpretação da lei. Segundo a pesquisa, a utilização expressa de referências pejorativas à raça ou à cor negra parece "não bastar para os tribunais reconhecerem o ato ilícito atentatório à dignidade do grupo" (MACHADO; LIMA; NERIS, 2016, p. 17), dado que nos casos estudados exigem, para além da exteriorização inequívoca do preconceito, que se faça prova da intenção de praticar a discriminação.

Essa exigência é uma interpretação que requer a prova de algo tão abstrato que praticamente exige que o autor confesse que teve um dolo racista no xingamento. A ideia de que se pode provar a intenção é uma ficção no Direito Penal. Essa exigência de prova é impossível, dado que o que se passa na cabeça de uma pessoa é algo inalcançável, a menos que seja exteriorizado e, inclusive, essa é a regra no Direito Penal que majoritariamente atua imputando intenção, mas, a partir de dados objetivos da realidade, ${ }^{11}$ não exigindo a comprovação da intenção. Outro ponto importante se refere à ausência de elemento subjetivo usado nas decisões para absolver, que geralmente não é adequadamente justificada. Assim:

\footnotetext{
10 Trecho da música: Veja os cabelos dela! Tiririca. Disponível em: https://www.vagalume.com.br/tiririca/vejaos-cabelos-dela.html. Acesso em: 2 set. 2020.

${ }^{11}$ Exposição de motivos da parte geral do Código Penal Brasileiro: "O critério da teoria puramente objetiva não revelou na prática maiores inconvenientes [...] O projeto optou pelo critério que mais adequadamente se
} 


\begin{abstract}
Juízes concluem que não há intenção de praticar preconceito, mas na maior parte dos casos não justificam por que as evidências demonstradas e a ofensa de cunho racial não demonstram o intuito racista. Apenas parece que os tribunais estão esperando um ato mais intenso de segregação, mas que de todo modo não fica nítido qual seja (MACHADO; LIMA; NERIS, 2016, p. 19-20).
\end{abstract}

Nesta conjuntura, considera-se que a grande problemática da ineficiência da lei, seja na fase investigativa, processual ou nas decisões judiciais, está no fato de que, ao não lograrem êxito com respostas adequadas dos órgãos judiciais, as autoridades conferem uma espécie de aval à sociedade para a prática de racismo.

Observa-se que as pessoas que praticam os crimes geralmente não publicam as ações em jornais de circulação ou rede sociais, pois produziriam provas contra si mesmas, embora haja exceções como nos casos de Simone André Diniz e Maria Júlia Coutinho (MARIA Julia..., 2015; PIRES, 2017).

\title{
Conclusão
}

Como afirma Sueli Carneiro (1996), nossos passos vêm de longe. Apesar dessa longa trajetória, a luta antirracista vem colhendo alguns frutos, ainda iniciais, decorrentes de uma jornada longa trilhada desde os nossos ancestrais. Apesar das conquistas, ainda é necessário tombar impasses que se remodelaram e inviabilizam a concretização dos objetivos que o povo brasileiro estabeleceu em 1988 com a Constituição da República Federativa do Brasil.

A partir da análise realizada no presente artigo, verifica-se que ainda há entraves legais que estão enraizados e difundidos nas relações sociais, que pregam valores que desprestigiam o corpo negro. Tais valores são transmitidos socialmente por meio de piadas, músicas, filmes, novelas, publicidade e comerciais em âmbito nacional.

As novas formas de transmissão de valores racistas não são lidas ou não querem ser lidas pelo legislativo e pelo judiciário brasileiro como crime de racismo, ou sequer, de injúria racial qualificada. Assim, verifica-se o grande entrave, ainda contemporâneo, no alcance de cumprimento e efetividade da proteção legal garantida em legislação, dado que as práticas racistas se reinventam e remodelam, alcançando aparência de normalidade, alcançando o afastamento da aplicação das normas.

opõe ao crescimento da criminalidade profissional, organizada e violenta, cujas ações se repetem contra vítimas diferentes em condição de tempo, lugar, modo de execução e circunstâncias outras marcadas por evidências e semelhanças [...]" (BRASIL, 1983, item 59). 
A esvaziamento da legislação antirracista não resulta apenas da não aplicação de pena, mas de um conjunto de elementos permissivos que são mecanismos legítimos estabelecidos socialmente, de práticas que imprimem valores negativos a determinado grupo social, o que fere o princípio da igualdade.

A partir dos resultados apresentados, considera-se que as instâncias judicial e legislativa se tornam promotoras da manutenção de desigualdades e de seu aprofundamento ao não reconhecerem as ações de discriminação travadas na sociedade, que imprimem valores negativos à população negra em contexto de mídias socais, músicas, propaganda, imagens, piadas e desentendimentos da vida cotidiana, o que acaba por chancelar essas práticas e manter as estruturas raciais na sociedade brasileira. Nesse contexto, o judiciário deixa de desempenhar papéis importantes na sociedade, quais sejam, o educativo e contra-majoritário.

Recomenda-se a revisão das penas previstas para injúria racial e para os crimes de racismo já previstos, de maneira que prevejam penas de reclusão maiores, no mínimo, do que quatro anos, de maneira a evitar a suspensão condicional da pena ou sua substituição por penas restritivas de direito. Ainda, recomenda-se a impossibilidade expressa de que os crimes de injúria racial e racismo sejam de culpabilidade questionável, ou seja, devem todos ser considerados dolosos, a fim de que sejam evitadas discussões jurisdicionais influenciadas pela minimização subjetiva das condutas.

Por fim, considera-se que o caminhar em direção à concretização do Direito à igualdade disposto na Constituição requer que os esforços sociais sejam voltados à promoção de respeito e valoração à imagem da população negra. É emergente a interpretação e aplicação de legislação antirracista eficaz, mas, para tanto é indispensável a construção de caminhos de educação racial aos intérpretes e aplicadores do direito.

\section{Referências}

ÁVILA, Thiago Andre Pierobom de (Org.). Acusações de racismo na Capital da Republica. Brasilia: MPDFT, 2017. Disponível em: http://www.mpsp.mp.br/portal/page/portal/documentacao_e_divulgacao/doc_biblioteca/bibli_servicos_produtos/BibliotecaDigital/BibDigitalLivros/TōōosOsLivros/Acusacoes_de_racismo_na_capital_da_Republica.pdf. Acesso em: 20 ago. 2020.

BOMBRIL retira 'krespinha' do mercado: acusações de racismo fazem marcas reverem produtos. BBC News Brasil, 18 jun. 2020. Disponível em: https://www.bbc.com/portuguese/brasil-53081428. Acesso em: 2 out. 2020. 
BRASIL. Presidência da República, Casa Civil. Subchefia para Assuntos Jurídicos. DecretoLei $n^{\circ}$ 2.848, de 7 de dezembro de 1940. Código Penal. 1940. Disponível em: http://www.planalto.gov.br/ccivil_03/decreto-lei/del2848compilado.htm. Acesso em: 21 ago. 2020.

BRASIL. Presidência da República, Casa Civil. Subchefia para Assuntos Jurídicos. DecretoLei $n^{\circ}$ 3.689, de 3 de outubro de 1941. Código de Processo Penal. 1941. Disponível em: http://www.planalto.gov.br/ccivil_03/decreto-lei/del3689.htm. Acesso em: 21 ago. 2021.

BRASIL. Presidência da República, Casa Civil. Subchefia para Assuntos Jurídicos. Lei $n^{\circ}$ 1.390, de 3 de julho de 1951. Inclui entre as contravenções penais a prática de atos resultantes de preconceitos de raça ou de côr. 1951. Disponível em: http://www.planalto.gov.br/ccivil_03/LEIS/L1390.htm. Acesso em: 20 ago. 2020.

BRASIL. Congresso Nacional. Câmara dos Deputados. Decreto-Lei $n^{\circ} 2.848$, de 7 de dezembro de 1940: Exposição de motivos n² 211, de 9 de maio de 1983 (Do Senhor Ministro de Estado da Justiça). 1983. Disponível em: https://www2.camara.leg.br/legin/fed/declei/1940-1949/decreto-lei-2848-7-dezembro-1940-412868-exposicaodemotivos-148972-

pe.html. Acesso em: 21 ago. 2020.

BRASIL. Presidência da República, Casa Civil. Subchefia para Assuntos Jurídicos. Lei $n^{\circ}$ 7.209, de 11 de julho de 1984. Altera dispositivos do Decreto-Lei $n^{\circ} 2.848$, de 7 de dezembro de 1940 - Código Penal, e dá outras providências. 1984. Disponível em: http://www.planalto.gov.br/ccivil_03/leis/1980-1988/l7209.htm. Acesso em: 20 ago. 2020.

BRASIL. Presidência da República, Casa Civil. Subchefia para Assuntos Jurídicos. Lei $n^{\circ}$ 7.437, de 20 de dezembro de 1985. Inclui, entre as contravenções penais a prática de atos resultantes de preconceito de raça, de cor, de sexo ou de estado civil, dando nova redação à Lei $\mathrm{n}^{\circ} 1.390$, de 3 de julho de 1951 - Lei Afonso Arinos. 1985. Disponível em: http://www.planalto.gov.br/ccivil_03/leis/l7437.htm. Acesso em: 21 ago. 2020.

BRASIL. Presidência da República, Casa Civil. Subchefia para Assuntos Jurídicos. Constituição da República Federativa do Brasil de 1988. 1988. Disponível em: http://www.planalto.gov.br/ccivil_03/constituicao/constituicao.htm. Acesso em: 20 ago. 2020.

BRASIL. Presidência da República, Casa Civil. Subchefia para Assuntos Jurídicos. Lei $n^{\circ}$ 7.716 de 5 de janeiro de 1989. Define os crimes resultantes de preconceito de raça ou de cor. 1989. Disponível em: http://www.planalto.gov.br/ccivil_03/leis/l7716compilado.htm. Acesso em: 21 ago. 2021. 
BRASIL. Presidência da República, Casa Civil. Subchefia para Assuntos Jurídicos. Lei $n^{\circ}$ 9.459, de 13 de maio de 1997. Altera os arts. $1^{\circ}$ e 20 da Lei $n^{\circ} 7.716$, de 5 de janeiro de 1989, que define os crimes resultantes de preconceito de raça ou de cor, e acrescenta parágrafo ao art. 140 do Decreto-lei $n^{\circ} 2.848$, de 7 de dezembro de 1940. 1997. Disponível em: http://www.planalto.gov.br/ccivil_03/leis//9459.htm. Acesso em: 21 ago. 2021.

BRASIL. Presidência da República, Casa Civil. Subchefia para Assuntos Jurídicos. Lei $n^{\circ}$ 12.033, de 29 de setembro de 2009. Altera a redação do parágrafo único do art. 145 do Decreto-Lei no 2.848, de 7 de dezembro de 1940 - Código Penal, tornando pública condicionada a ação penal em razão da injúria que especifica. 2009. Disponível em: http://www.planalto.gov.br/ccivil_03/_ato2007-2010/2009/lei/l12033.htm. Acesso em: 21 ago. 2020.

BRASIL. Presidência da República, Casa Civil. Subchefia para Assuntos Jurídicos. Lei $n^{\circ}$ 12.288, de 20 de julho de 2010. Institui o Estatuto da Igualdade Racial; altera as Leis nos 7.716, de 5 de janeiro de 1989, 9.029, de 13 de abril de 1995, 7.347, de 24 de julho de 1985, e 10.778, de 24 de novembro de 2003. 2010. Disponível em: http://www.planalto.gov.br/ccivil_03/_ato2007-2010/2010/lei//12288.htm. Acesso em: 21 ago. 2020.

BRASIL. Presidência da República, Casa Civil. Subchefia para Assuntos Jurídicos. Lei $n^{\circ}$ 12.527, de 18 de novembro de 2011. Regula o acesso a informações previsto no inciso XXXIII do art. $5^{\circ}$, no inciso II do $\S 3^{\circ}$ do art. 37 e no $\S 2^{\circ}$ do art. 216 da Constituição Federal; altera a Lei $n^{\circ}$ 8.112, de 11 de dezembro de 1990; revoga a Lei $n^{\circ} 11.111$, de 5 de maio de 2005, e dispositivos da Lei $n^{\circ} 8.159$, de 8 de janeiro de 1991; e dá outras providências. 2011. Disponível em: http://www.planalto.gov.br/ccivil_03/_ato20112014/2011/lei//12527.htm. Acesso em: 21 ago. 2020.

BRASIL. Tribunal de Justiça do Espírito Santo. Sentença. Processo: 000151519.2011.8.08.0024. 4 nov. 2013. Disponível em: https://www.migalhas.com.br/arquivos/2013/11/art20131107-13.pdf. Acesso em: 13 set. 2020.

CARNEIRO, Sueli. Racismo e discriminação. Cadernos de Pesquisa, n. 4, p. 59-95, 1996. Disponível em: http://bibliotecavirtual.cebrap.org.br/arquivos/racismo_e_discriminacao_e.pdf. Acesso em: 2 set. 2020.

'É PELO CORPO que se reconhece a verdadeira negra' - Devassa Negra deve alterar conteúdo "racista e sexista" de propaganda. Portal Geledés, 2 mar. 2012. Disponível em: https://www.geledes.org.br/e-pelo-corpo-que-se-reconhece-a-verdadeira-negra-devassanegra-deve-alterar-conteudo-racista-e-sexista-de-propaganda/. Acesso em: 20 set. 2020.

MACHADO, Marta Rodriguez de Assis; LIMA, Márcia; NERIS, Natália. Racismo e insulto racial na sociedade brasileira: dinâmicas de reconhecimento e invisibilização a partir do direito. Novos estudos CEBRAP [online], v. 35, n. 3, p. 11-28, nov. 2016. https://doi.org/10.25091/S0101-3300201600030001 
MARIA Júlia Coutinho, a Maju, é vítima de comentários racistas no Facebook. G1, 3 jul. 2015. Disponível em: http://g1.globo.com/pop-arte/noticia/2015/07/maria-julia-coutinhomaju-e-vitima-de-racismo-no-facebook.html. Acesso em: 11 set. 2020.

MATO GROSSO DO SUL (Estado). Tribunal de Justiça - TJMS. Apelação Criminal n. 2005. 018057-8/0000-00. Campo Grande: TJMS, 2005.

MOREIRA, Adilson. Racismo recreativo. São Paulo: Jandaíra, 2019. Coleção Feminismos Plurais.

NÃO É OFENSIVA propaganda da Devassa com referência ao corpo da mulher negra. Migalhas, 8 nov. 2013. Disponível em: https://www.migalhas.com.br/quentes/190053/nao-eofensiva-propaganda-da-devassa-com-referencia-ao-corpo-da-mulher-negra. Acesso em: 13 set. 2020.

NOGUEIRA, Oracy. Tanto preto quanto branco: estudo de relações raciais. São Paulo: T. A. Queiroz, 1985.

NUCCI, Guilherme de Souza. Manual de processo penal e execução penal. 12. ed. rev. atual. e ampl. Rio de Janeiro: Forense, 2015.

PIRES, Breiller. Grêmio e Aranha, uma história de racismo perverso e continuado. El Pais, 17 jul. 2017. Disponível em: https://brasil.elpais.com/brasil/2017/07/17/deportes/1500309484_868649.html. Acesso em: 12 set. 2020.

QUEIROZ, Guilherme. Marca de roupas Animale é condenada por episódio de racismo. Veja, 6 ago. 2019. Disponível em: https://vejasp.abril.com.br/cidades/marca-de-roupas-animale-e-condenada-por-episodio-de-racismo/. Acesso em: 14 set. 2020.

RIO DE JANEIRO (Estado). Tribunal de Justiça do Estado de Rio de Janeiro - TJRJ. Apelação Criminal n. 1069/98. Rio de Janeiro: TJRJ, 1998.

SANTAHELENA, Raul. Dove enfrenta nova polêmica sobre racismo em propaganda. Exame, 9 out. 2017. Disponível em: https://exame.com/marketing/dove-enfrenta-nova-polemica-racista-em-propaganda/. Acesso em: 12 set. 2020.

SÃO PAULO (Estado). Assembleia Legislativa. Lei $n^{\circ} 14.187$, de 19 de julho de 2010. Dispõe sobre penalidades administrativas a serem aplicadas pela prática de atos de discriminação racial. 2010. Disponível em: https://www.al.sp.gov.br/repositorio/legislacao/lei/2010/lei-14187-19.07.2010.html. Acesso em: 13 set. 2020. 
SÃO PAULO (Estado). Assembleia Legislativa. Decreto $n^{\circ} 63.979$, de 19/12/2018. Institui e disciplina sistema de pontuação diferenciada para pretos, pardos e indígenas em concursos públicos destinados à investidura em cargos e empregos no âmbito do serviço público paulista, nos termos da Lei Complementar $n^{\circ} 1.259$, de 15 de janeiro de 2015, e dá providências correlatas. 2018. Disponível em: https://www.al.sp.gov.br/norma/188921. Acesso em: 13 set. 2020.

SÃO PAULO. Tribunal de Justiça do Estado de São Paulo - TJSP. Apelação Criminal $n$. 48272000. São Paulo: TJSP, 2000. 